\title{
Who gets the HANPP (Human Appropriation of Net Primary Production)? Biomass distribution and the bio-economy in the Tana Delta, Kenya
}

\author{
Leah Temper ${ }^{1}$ \\ Universitat Autònoma de Barcelona, Spain
}

\begin{abstract}
The Tana Delta, on the east coast of Kenya near Somalia, comprises riverine mangrove forests, wetlands and rangelands and is home to a range of indigenous pastoralist, farmer and fisher communities, whose traditional multi-user livelihood strategies have helped preserve exceptional local biodiversity. This study assesses conflicts over biomass through an analysis of Human Appropriation of Net Primary Production (HANPP), an indicator used by system ecologists that quantifies human-induced changes on the productivity and harvest of biomass flows. HANPP is calculated by seeing how much of the net primary production (NPP) of biomass flows created through solar energy are appropriated by human activity, and how much is left in the ecosystems for other species. In this article we introduce calculations of the HANPP in political ecology by studying not only the distribution of biomass between humans and non-humans but also (and this is the main point) between different groups or social classes of humans. We also ask what alliances are being made to protect biodiversity and keep livelihoods intact. In a sugar cane plantation economy, biomass production and the proportion appropriated by humans may increase, the Orma pastoralists and the Pokomo farmers would be dispossessed, less biomass would be available for local 'wild' biodiversity, and a much larger proportion of the NPP would be exported as sugar or ethanol.
\end{abstract}

Key words: Human appropriation of biomass; bioeconomy; biodiversity; property rights; pastoralists; sugar cane; wetlands.

\section{Résumé}

Le Delta du Tana, sur la côte est du Kenya près de la Somalie, comprend mangroves riveraines des forêts, des zones humides et les pâturages. Il est le territoire des éleveurs, agriculteurs et les communautés de pêcheurs, et leurs stratégies de subsistance diverses ont contribué à préserver la biodiversité locale exceptionnelle. Cette étude évalue les conflits sur la biomasse à travers une analyse d'appropriation humaine de la production primaire nette (HANPP), un indicateur utilisé par les écologistes du système qui quantifie les changements induits par l'homme sur la productivité et la récolte des flux de biomasse. HANPP est calculé en voyant combien de la production primaire nette (NPP) de la biomasse flux créé par l'énergie solaire sont consommés par l'activité humaine, et combien est laissé dans les écosystèmes pour les autres espèces. Dans cet article, nous présentons les calculs de la HANPP dans un cadre de l'écologie politique en étudiant non seulement la répartition de la biomasse entre les humains et les non-humains, mais aussi (ce qui est le principal point) entre les différents groupes ou classes sociales de l'homme. Nous demandons aussi quelles alliances sont faits pour protéger la biodiversité et maintenir les moyens de subsistance intact. Dans une économie de plantation de canne à sucre, si la production de biomasse et la proportion appropriée par les humains augmente, les éleveurs Orma et les agriculteurs Pokomo seraient dépossédés, moins la biomasse seront disponibles pour la biodiversité locale «sauvage», et une plus grande proportion de la NPP serait exporté que le sucre ou l'éthanol.

Mots clés: appropriation humaine de la biomasse; bioéconomie; biodiversité; droits de propriété; pasteurs; canne à sucre; zones humides.

\footnotetext{
${ }^{1}$ Dr. Leah Temper, Institut de Ciència i Tecnologia Ambientals (ICTA), Universitat Autónoma de Barcelona (UAB), 08193, Bellaterra, Barcelona, Spain. Email: leah.temper "at" gmail.com. Thanks to the two anonymous referees for their comments, and to Simon Batterbury, Joan Martinez-Alier and Alf Hornborg for their inputs and close reading. Sincere gratitude to Nature Kenya, the East African Wildlife Society, Maulidi Diwayu and to the communities of Vumbwe and Baandi for their time and participation. This is the sixth article in Hornborg A. and Martinez-Alier J. (eds.) "Ecologically unequal exchange and ecological debt", special section of the Journal of Political Ecology 23: 328-491.
} 


\section{Resumen}

El Delta del río Tana en la costa de Kenya cerca de Somalia, comprende bosques ribereños de manglar, humadales y tierras de pastos. Es el hogar de comunidades locales de pastores, agricultures y percadores, cuyas estrategias multi-uso para conseguir la subsistencia han ayudado a preservar una biodiversidad excepcionalmente rica. Este trabajo estudios los conflictos sobre el uso de la biomasa a través del análisis del indicador HANPP ("apropiación humana de la producción primaria neta") que es usado por la ecología de sistemas para cuantificar los cambios en la producción y cosecha de biomasa inducidos por la acción humana. La HANPP se calcula viendo cuánta de la producción primaria neta de los flujos de biomasa creados por la energía solar es apropiada por las actividades humanas, y cuánto queda en los ecosistemas para otras especies. En este artículo, introducimos los cálculos de la HANPP en la ecología política al estudiar no sólo la distribución de la biomasas entre los humanos y no-humanos sino también (y éste es el punto principal) entre distintos grupos o clases sociales de humanos. También explicamos las alianzas que se establecen para proteger la biodiversidad y mantener los modos de vida de las poblaciones. En una economía de plantación de caña de azúcar, tanto la producción de biomasa como la proporción de ésta apropiada por los humanos aumentarían, los Orma y los Pokomo (respectivamente, pastores y agricultores) serían desposeídos, quedaría menos biomasa a disposición de la biodiversidad local "silvestre" y una parte mucho mayor de la producción priaria neta sería exportada como azúcar o etanol.

Palabras clave: Apropiación humana de la biomasa; bioeconomía; biodiversity; derechos de propiedad; pastores; caña de azúcar; humedales.

\section{Introduction}

Growing acquisition of farmland is being driven by several broad processes (Deininger and Byerlee 2010; GRAIN 2008; Zoomers 2010), including the food crisis of 2008, rising meat consumption in Asia, biofuel targets, demand for wood and paper, and new long-term investment opportunities as a response to low interest rates, among others. This article zooms in on the connection between purchases of land and the emerging 'biomass economy', analysing biomass distribution in a region targeted for land-grabbing from both biophysical and political ecological perspectives.

The bio-economy or 'sugar economy' refers to the vision of significantly increasing biomass as a feedstock for exosomatic ${ }^{2}$ energy and industrial products. This includes increased agrofuel production, as well as projected use of agricultural 'wastes and residues.' It also hinges on hopes of biotechnological advances in second-generation bio-fuels. The bio-economy can also be viewed more broadly — as the push to commoditise the biomass resources that are currently not yet in the market and to increase the biomass that comes to the market.

While The Economist (2009) glibly asserted that "there is plenty of biomass to go around", this article uses a conceptual framework of 'social metabolism' and 'colonisation of natural systems' in society-nature interactions to question this assertion (Fischer-Kowalski and Haberl 2012). The socio-ecological indicator, HANPP (Human Appropriation of Net Primary Production) provides a tool to offer greater insight into the potential social and environmental impacts of the extensification and intensification of industrial agriculture.

By examining biomass use and distribution among actors and uses, I aim to shed light on the following questions:

- Is there enough biomass to go around?

- What are the current uses and distribution of biomass resources at global and local levels?

- What new conflicts are we seeing over plant matter, both crops and 'waste residues'?

- In a future bio-economy, will there be more biomass and for whom?

\footnotetext{
${ }^{2}$ In human thermodynamics exosomatic energy, as contrasted with endosomatic energy (bodily metabolism), is the useful energy throughput outside human bodies.
} 
- And finally, how much biomass will be left behind in nature, available to preserve biodiversity?

This article examines these questions through a case study in the Tana Delta, Kenya, one of the new commodity frontiers in the recent large-scale land acquisitions (Moore 2000). The HANPP is deployed to examine biomass flows in the delta, combining a biophysical perspective with a political-ecology analysis of the interests, stakes, and power politics in the delta, to answer Bernstein's four fundamental questions of agrarian political economy (Bernstein 2007):

- Who owns what?

- Who does what?

- Who gets what?

- And what do they do with the agrarian surplus?

The Tana Delta, on the coast of Kenya near Somalia, comprises riverine forests, wetlands and rangelands and is home to a range of indigenous pastoralist, farmer and fisher communities, whose traditional multi-user livelihood strategies have helped preserve exceptional local biodiversity. Numerous development projects focussing on plantation crops, primarily fuel crops such as Jatropha, oil seeds, and sugarcane. Titanium mining and gas and oil exploration have also targeted the region. ${ }^{3}$ Of these, sugarcane represents the largest area with projects that were planned (although many now defunct) such as the Tarda project (20,000 ha), MAT International (110,000 ha) and another from Kwale International Sugar Company Limited (Kiscol) of 8,000 ha. Looking at old and new agrarian conflicts in the Tana Delta, we ask:

- What will the impacts of new land deals be on local food availability?

- What can the history of the delta tell us about future potential for conflict and differentiated impacts on the people and local environment?

- What alliances are being made to protect the biodiversity and keep livelihoods intact?

The first section introduces the conceptual tools and theoretical framework, expanding on the concept of the 'sugar economy' as a socio-metabolic transition (Haberl 1997; Sieferle 2001) and material and energy flow analysis (MEFA) as valuable instruments in gauging sustainability and potential sites of conflict over biomass. The second section contextualises the case study of the Tana Delta in Kenya as a site of conflict over biological resources through an analysis of property rights and its historical dynamics. The third section presents the results of the analysis of biomass distribution. The fourth and fifth sections offer discussion of the results and the conclusions.

\section{Political ecological economics}

Political ecology can be defined as the study of conflicts over access to natural resources and services and over the burdens of impacts that arise because of inequalities in power, property and income among human groups (Martinez-Alier 2002). Ecological economics, meanwhile, builds upon a thermodynamic foundation of economics, attempting to place the economy within the natural world and demonstrate the impact that economic throughput has on natural capital and biological processes. 'Social metabolism' focuses on how social systems reproduce themselves biophysically (e.g. the human population, built infrastructure,

\footnotetext{
${ }^{3}$ Following a court ruling in 2013, all projects were put on hold pending a planned Master Land Use Plan for the Delta that resulted in large part through the advocacy of Nature Kenya and other organized opposition to the TISP and other projects. The Master Land Use Plan was finalized in 2014 (Odhengo et al. 2014) and calls for a hybrid zoning strategy, but as of 2016 there has been no news of these projects being reinitiated.
} 
artefacts and livestock) through a continuous energetic and material exchange with their natural environment (and other social systems). Social metabolism can be quantified in terms of energetic and material flows per time period, usually a year, and such flows can be expressed per capita or by unit area.

This study assesses conflicts over biomass through an analysis of Human Appropriation of Net Primary Production (HANPP) (Haberl 1997; Haberl et al. 2009; Vitousek et al. 1986), an integrated socioecological indicator used by system ecologists that quantifies human-induced changes to the productivity and harvest of biomass flows (Haberl et al. 2014). HANPP is calculated by seeing how much of the net primary production (NPP) of biomass flows created through solar energy is appropriated by human activity, and how much is left in the ecosystems for other species. In this way, HANPP has been likened to a way to measure the 'scale' of human activities compared to natural processes and human domination of the earth.

HANPP aims to understand what fraction of biospheric resources in a system is being consumed by humans as an indicator of environmental pressure. While not as well known as the 'ecological footprint', HANPP studies provide a valuable metric for gauging whether humanity is approaching some sort of capacity, or limits to its consumption of the biosphere. The first estimates at the global level, by Vitousek et al. (1986) estimated that humanity was using about 32-40\% of global NPP. More recent estimates hover around 25\% (Imhoff et al. 2004; Krausmann et al. 2013). However, this conceals considerable variation between nations. India for example has a national average HANPP of 73\% as compared to Japan's average of 22\% (Singh et. al 2012).

HANPP originated as a global scale indicator, and fewer calculations have been done at the local level (see however Andersen et al. 2015: Singh and Grünbühel 2003). Applications at smaller scales down to the regional and local level can hold important policy implications as they can demonstrate increasing vulnerability of a local population to shortfalls in NPP, and thus serve as early alerts (Running 2014).

A significant contribution and methodological innovation of the current article is its concern with the distribution of the human appropriation of primary production between two competing human groups sharing the same territory, and their distinct strategies for appropriating biomass through agriculture, grazing, and other methods. Thus, we are not only concerned about the competition for biomass between humans and 'wild' biodiversity. We also want to show how there are distributive conflicts among humans seeking a share of the HANPP. This is less trivial than it may sound, because human activities do not only increase the HANPP, they might also increase NPP (for instance, by the use of fertilisers or by irrigation). ${ }^{4}$

Thus, the expansion of tree plantations increases the HANPP and often leads to conflicts with indigenous populations forced out by companies growing eucalyptus or pine trees. Similarly, in a case such as the Tana Delta, agrofuels or biofuels would increase the HANPP to the detriment of other species, and also to the detriment of some humans, leading to increased conflicts over sites of biomass production (GRAIN 2008). To understand the aetiology of these looming conflicts, this article uses a perspective combining political ecology and ecological economics, responding to M'Gonigle's exhortation to unify political ecology and ecological economics and to situate human actions within the processes of the natural world, and to legitimise them to the degree that they can co-exist in balance with that world (1999).

\section{Back to the land? The socio-metabolic implications of the bio-economy}

The study of socio-metabolic transitions shows how land and energy use and resource extraction and consumption transform over time, fundamentally re-organising the relationship with the natural environment. Haberl, Erb and Krausmann (2010) discern three fundamentally different socio-metabolic regimes: huntergatherers, the "controlled solar energy system" (Sieferle 2001) of agrarian societies, and industrial societies dependent on fossil fuels.

The spectre of the biomass regime foreshadows an important socio-metabolic shift in human relationships with the earth. The bio-economy denotes the idea of an industrial order that relies on biological

\footnotetext{
${ }^{4}$ NPP is a rate of biomass growth on a given area in a defined time (usually one growing season, or year). It can be expressed in terms of dry matter (kg. of biomass $\left./ \mathrm{m}^{2} \mathrm{yr}\right)$ as well as in energetic units $\left(\mathrm{MJ} / \mathrm{m}^{2} \mathrm{yr}\right)$.
} 
materials, processes and services (ETC Group 2010). The switch to agrofuels is the primary element in this vision, but investment and corporate interest are also focusing in on the enabling technologies of the switch to synthetic biologies and nanotechnologies that will allow the development of second-generation biofuels from lignocellulosic materials like wood. In essence then, the biomass economy is based on the idea of a return to a metabolic regime based on solar energy flow, the primary energy source in pre-industrial societies as a fix to the depletion of sources and sinks for fossil fuels that provided humankind with an industrial standard of living.

In this way, the bio-economy is posited as the long-awaited revolution in the creation of "ecological surplus" (Moore 2009) and a means to finally transcend ecological limits with a rhetoric doused in 'green' imagery about the transition from black carbon to green carbon. For example: "...the enthusiasm for plant derived products... tantalizingly might offer a way out of the zero-sum game between economic growth and environmental protection" (Frow et al. 2009: 18).

Such hubris surrounding the promise of biofuels as a renewable energy source augurs the growing importance of the HANPP indicator for understanding the widening and deepening of human colonization of land and natural processes, that this socio-metabolic detour would entail. Researchers argue at the global scale "...that a transition from fossil fuels back to an area-related energy system (with agro-fuels) is not feasible at present population densities because of the low Energy Return on Energy Input (EROEI) and the increase in the HANPP that it would imply" (Haberl et al. 2011). At the local scale, HANPP provides a valuable analysis because it illustrates how competition and conflicts over land can also be seen as conflicts over the ecosystem services that can be derived from a particular plot of land - its potential productivity.

In common with a large part of humanity, the inhabitants of the Tana Delta continue to rely almost entirely on local biomass production for their energy needs. An examination of the socio-metabolic profile of the population therefore provides a useful case of how the ability to appropriate biomass outside the market relates to the wellbeing of the distinct tribal groupings; and how the distribution among groups also offers insight into the conflict between them, as pastoralists and agriculturalists. HANPP is also a measure of sustainability and sustainable resource use in a spatially demarcated area. It gives an indicator of the environmental pressure exerted upon the delta, and pressure on its biodiversity (Haberl et al. 2007b).

This paper discusses implications for HANPP if widespread cultivation of sugar were to proceed. This exercise aims to elucidate competing claims for the HANPP among different groups (human and animal) within the delta, and their relationships to each other, and give insights into any conflicts for biomass at wider scales.

\section{Methodology and data}

Two field trips were undertaken to the Delta in August of 2008 and in July of 2010. Structured and semi-structured interviews were carried out with government officers and employees and environmental NGOs in Kenya and the main town, Malindi. I also worked in the delta, with employees of the the Tana and Athi Rivers Development Authority (TARDA), and villagers from Luo, Orma, Wardei, and Pokomo communities. Interviews with key informants at the village level were conducted and in July 2010 in-depth surveys of biomass use, purchasing and household stocks were administered to eight Pokomo households, eight Orma households and one Wata household. Fields and other areas were measured by transect walks and GPS. These results were cross-referenced with literature, information from local government offices and census and agricultural data to corroborate the data and arrive at biomass flow cross-estimates.

To understand resource conflict in the delta I analyse it as a process of accumulation through biomass appropriation, employing a modified version of the methodology developed by the Institute of Social Ecology in Vienna to create a model of how the actors in the Tana Delta Irrigation Project (TDIP) area appropriate biomass (Schandl et al. 2002; Singh et al. 2010). Local level biomass studies give "...insights into the functioning of the subsistence economy normally underrepresented in national studies as well as insights into cultural coping strategies for dealing with land use change and industrialization" (Schandl et al. 2002). 
HANPP is generally calculated in 5 steps and requires:

(1) calculating the Net Primary Production (NPP) of the potential vegetation, or the amount of NPP that would have prevailed in the absence of any human presence or intervention;

(2) calculating the NPP of actual or current vegetation (before harvest) in the face of human presence and interventions;

(3) calculating the annual biomass harvest by the population;

(4) calculating the remaining NPP available in the ecosystem (after harvest) and, finally,

(5) calculating the HANPP by subtracting the remaining NPP (after harvest) from the potential NPP.

Because our interest here is on production, consumption and distribution, this paper primarily focuses on step three, the HANPP of harvest. This is denoted as HANPPharv and includes biomass harvested or killed during harvest in a year (Erb et al. 2009; Haberl et al. 2014) including crop biomass, wood harvest and harvest by grazing animals. Harvested NPP can be split into a 'used' component (that enters the socioeconomic system; Krausmann et al. 2008) and 'unused' (the part that is harvested but remains in the ecosystem, including crop residues, livestock feces and burned biomass), which is termed 'backflows to nature.'

First, I describe the current biomass appropriation of two villages, each representative of the two primary communities in the Delta. I then use global HANPP data, the primary data and current and future land use data to guide a discussion on future appropriation and distribution of such biomass under the proposed large-scale sugar production project. Thirdly, HANPP provides a heuristic device for tracking ecosystem and social transformations and for demonstrating the potential for conflict and environmental changes related to shifts in access to biomass. It should be kept in mind that the figures present estimates, that aim to be useful in understanding socio-metabolic profiles and energy flows in the delta.

Data is given in Tonnes Dry Matter (TDM) or in GJ (Gigajoules, one billion $\left[10^{9}\right]$ joules). In energetic studies, all flows are expressed in mass units (i.e. fresh weight as given in the source converted to dry matter with the use of conversion factors) as well as in energetic units (i.e. gross calorific value, nutritive [calorific] value).

Conversion factors are used to convert production of crops into energy values, depending on their water content. ${ }^{5} \mathrm{~A}$ standardised water content of $14 \%$ is used for timber and fodder. Inputs that are not marketed like green fodder grazed by cattle are also accounted for with a standardised water content of $14 \%$ (Schandl et al. 2002). One kg dry matter biomass roughly equals $18.5 \mathrm{MJ}$ gross calorific value (upper heating value) or $0.5 \mathrm{~kg}$ carbon. Unused residues on cropland were derived using harvest indices taken from Krausmann et al. (2008). ${ }^{6}$ Grazed biomass was assessed by utilizing livestock numbers to account for total feed demand. Due to data limitations our NPP calculations were restricted to aboveground productivity only. This includes growth of plant organs above the soil (stems, leaves, fruits, etc.) without taking into account growth of plant organs below the surface, for example, roots.

\section{The study area: the Tana Delta and TDIP}

The Tana Delta (Figure 1) is one of the most important wetlands in Africa. It comprises 130,000 ha, of which 69,000 ha are regularly inundated (Hughes 1984, 1990) and hold habitats ranging from riverine forests, grasslands, savannahs, bushland, lakes, mangroves, dunes, beaches, and estuaries that support rich biodiversity including over 350 bird species, buffaloes, hyenas, hippopotami and the Nile crocodile. The Tana

\footnotetext{
${ }^{5}$ Maize is calculated at $14.7 \mathrm{mg} / \mathrm{kg}$, pulses at $13 \mathrm{mg} / \mathrm{kg}$ and fruit at $2.3 \mathrm{mg} / \mathrm{kg}$ and vegetables at $1.3 \mathrm{mg} / \mathrm{kg}$.

${ }^{6}$ Harvest indices range from ratios of 3.2 residue to crop for maize, to 0.6 for green grams (mung bean, Vigna radiata) for example.
} 
is also home to two endangered primates - the Tana River Red Colobus (Procolobus rufomitratus

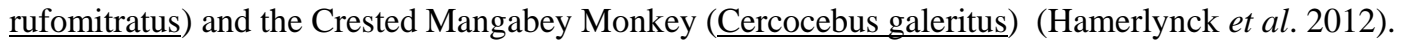

In a bio-economy, any land or water body that can sustain plant matter gains enhanced value as a potential site for biomass production. This is particularly true of potentially irrigable areas, as they can potentially produce significantly larger volumes of biomass. The Tana River flood plain, with its high water table and frequent flooding, is by far the most productive habitat along the north Kenya coast and holds $50 \%$ of the potential irrigable area in the country (Andrews 1975).

The two primary ethnic communities living in the delta are the Pokomo, who are Bantu-speaking Christian sedentary farmers, and the Orma, who are Kushitic-speaking Islamic, and primarily nomadic pastoralists. The remaining inhabitants include the Wardei pastoralists, Luo fishermen, and other tribes. The Pokomos practice flood recession agriculture along the low-lying fertile flood plains adjacent to the banks of the river, which floods seasonally, and grow maize and bananas and other vegetables for subsistence, and mangoes and rice as cash crops (Terer, Ndiritu and Gichuki 2004)

The delta is an important dry season grazing area for the pastoralists, and livestock travel from as far away as Somalia and Ethiopia. The Environmental Impact Assessment (EIA) for the Tana Integrated Sugar Project estimates that the delta hosts about 60,000 head of cattle during the dry season, while 20,000 graze permanently in the area (HVA International 2007). In contrast, the Master Land Use Plan give figures ranging from 200,000 in the wet season to 700,000 cattle present in the delta during the dry season. Because livestock travel from Somalia and Ethiopia to the delta and the influx is highly dependent on climatic fluctuations, further research is needed to arrive at more precise estimates. In general, pastoralists in the delta maintain a higher standard of living than the agriculturalists. They oppose any project that could threaten their livestock and reduce grazing areas. The Pokomo, in contrast, are more sympathetic towards agricultural development projects but are wary, due to unfulfilled promises in the past.

The environmental conservation group Nature Kenya, one of the main defenders of the delta, drafted a petition to the Kenyan high court, with members from both communities listed as petitioners. They highlighted eight proposed projects which are noted as forming part of the 'scramble for the delta', including exploration for titanium by Tiomin Kenya Limited in the Kipini area. The largest are the Tana Integrated Sugar Project (TISP), which was granted 40,000 ha, an increase from the 28,000 ha it owned previously, and MAT International, which is also interested in sugar-cane plantations (30,000 ha of which would be in the delta and 90,000 ha outside). If all these projects were to go ahead, at least 100,000 ha of the delta would be turned into monoculture plantations.

This article focuses primarily on the impacts of the Tana Integrated Sugar Project (TISP) project, a joint venture between Mumias, one of the most important sugar producers in Kenya, and the Tana and Athi Rivers Development Authority (TARDA). According to the EIA the project would cover 22,000 ha of the floodplain and foresees producing the most inexpensive sugar on the continent at US\$160 a tonne (HVA International 2007). ${ }^{7}$ The project would also produce ethanol for fuel and co-generation of electricity (HVA International 2007). There are 18 villages with an estimated 25,000 people, split more or less evenly among pastoralists and farmers that stand to be impacted by the project.

\section{Farmers, herders and white elephants in the Delta}

Co-existence in the delta between the communities is uneasy, sometimes leading to violence. Tribal conflict between the Pokomo and the Wardei-Orma occurred in 2000-2001 and again in 2012. Yet such tensions are not new, and nor can they be attributed to increasing resource scarcity or unclear property rights.

As in many places throughout Africa, property rights in the delta are complex and overlapping, with concurrent systems of private, public, and common land and different rights of access - usufruct, leasehold, and freehold. Much of the land in the delta is trust land, held in trust and administered by the county council for the "benefit of the persons ordinarily resident of that land." This trust land may be set aside for purposes

\footnotetext{
${ }^{7}$ Currently the most efficiently produced sugar costs US\$200 a tonne (Mugambi 2009).
} 
deemed to benefit the residents, or transferred to the government (Okoth-Ogendo 1991). Apart from property rights over land, there are access rights to water. For example, among the Orma, wells are owned by the person who first dug them, and then their patrilineal descendants (Ensminger and Rutten 1991). While the Pokomo lay claim to the land along the river banks to practice agriculture, the Orma stake their claim over the river waters and oxbow lakes.

While some theorists (influenced by Coase 1960) hold that clearly defined property rights should reduce conflict by creating shared expectations and through the creation of markets for damages; attempts to formalise rights that were previously customary thus can be a source of conflict themselves. Thus one of the triggers for the flare-up of inter-tribal violence in the delta in 2000-2001 was the actions of the Land Adjudication Commission, begun in 2000, creating a sharp split between the Pokomo, who favoured a liberal land policy based on individual ownership, and the Orma/Wardei, who preferred a communal system that allowed access for themselves and their cattle. Traditionally, the Pokomo and Orma observed specific customary rituals and practices that allowed the Orma herders to gain access to water-points and pasture on the banks of the Tana River, especially during dry season. Customary practices defining these rights "...emerged over the years, revealing a long interactive and integrative history of the two communities" (Kagwanja 2003: 140).

Ecological conditions are also variable, and the year 2001 was a dry one, adding fuel to the fire. The long rainy season floods fail on average in two or three years out of ten, and the short rainy season floods fail once in every two years. The erratic rainfall (500-800 mm per year) makes agriculture a risky enterprise in the Lower Tana, in the sense that sole dependence on agriculture can be tricky and thus locals have adopted a variety of livelihood strategies they can fall back on in drier years when yields are lower (Hamerlynck et al. 2010). The floods and the droughts that assail the region are also a product of anthropogenic change wrought by deforestation and dams upstream. The construction of hydroelectric power dams between 1968 and 1988 in the upstream parts of the Tana substantially reduced peak flows, have disrupted transhumance patterns and led to decreased biomass production, while offering few benefits. The Kiambere dam, completed in 1993, provided 140 megawatts of electrical power to Kenya's growing urban population. However, over 6,000 people were displaced without any compensation and most of the communities of the delta are still without electricity (Kagwanja 2003).

Other contentious projects include the Tana River Primate Reserve (TRPR). The World Bank was ordered to pay SH 634 million (US\$6.3 million) compensation to the displaced after the high court in Mombasa found that the World Bank and the Global Environmental Facility (GEF) failed to meet its promises to provide 15 acres (6 ha) per household, a house, compensation for lost trees and crops and SH 50,000 (US\$496) per family (Machuhi 2010). The most spectacular failure was perhaps the Bura Irrigation Scheme, implemented in 1978, with the original aim of settling around 5,000 farmers in 23 villages to grow cotton and maize on 6,700 ha of land that was crippled by corruption and mismanagement. In a country with a per capita income of about US\$350 per year at the time, the project spent an incredible US\$35,000 for every settler (Horta 1994). Yet today, the settlers are poorer than before and the area is a wasteland, overrun by the invader bush mathenge (Prosopis juliflora, itself a biofuel ${ }^{8}$ ). The most recent 'white elephant' project was the Tana Delta Irrigation Project (TDIP) rice scheme, managed by the Tana and Athi River Development Authority (TARDA). The TDIP represented a switch in policy from irrigation schemes with settlement and freeholders, to new plans for 'economically motivated' commercial estates with a few out-growers. Yet only a few months after starting full operations, the TDIP rice scheme collapsed due to flooding after the El Niño rains in 1997 (Luke, Hatfield and Cunneyworth 2005).

8 http://www.businessdailyafrica.com/Corporate-News/Firm-plans-to-generate-power-from-Mathenge-plant---/539550$\underline{2606746-5 \mathrm{tml} 1 \mathrm{xz} / \mathrm{index} . \mathrm{html}}$ 


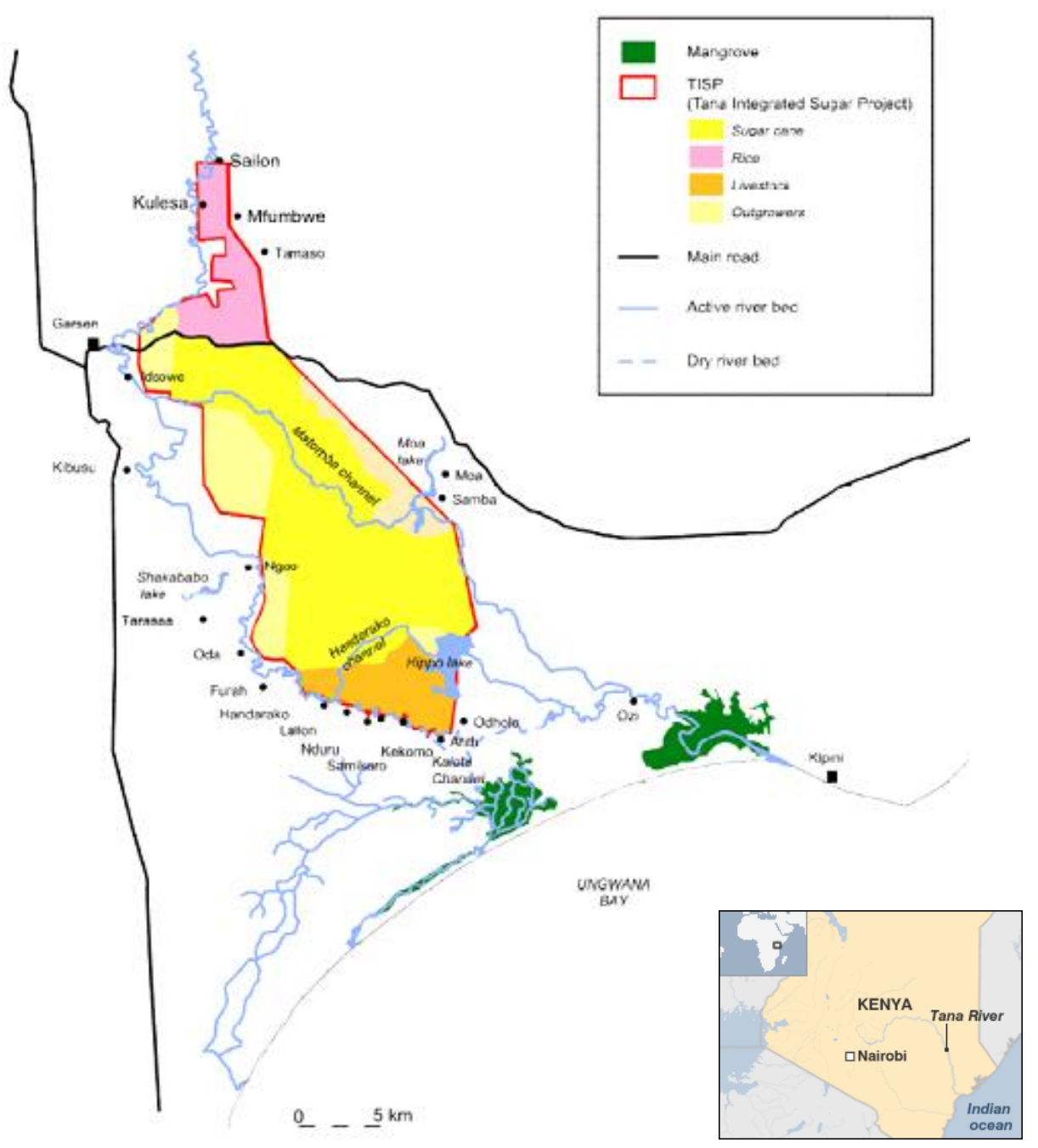

Figure 1. The Tana Integrated Sugar Project. Source: Olivier Hamerlynck and Stephanie Duvail.

The TDIP scheme removed 2,500 acres (1,042 ha) of either utilised or available cultivable floodplain land lying within Pokomo-demarcated lands as part of the project's total of 10,000 acres (4,047 ha) and also converted former grazing areas. The communities took TARDA to court in 1995 trying to reclaim the land that was expropriated from them. In 2007, despite the fact that the case is still pending, a new Mumias sugar project was planned in the same disputed area. ${ }^{9}$

\section{The Mumias Project and the TDIP}

The Mumias Project involves recuperating the rice scheme, and growing sugar in an estate over 16,000 ha and another 4,000 ha for out-growers, as well as a livestock component. Mumias has plans to install an 8,000 tons-per-day sugar mill and distil 23 million litres of agro-fuel ethanol per year from molasses, a cane byproduct. It would also produce 34 megawatts of electricity per day from bagasse (the dry residue left after the extraction of juice from sugar cane). Figure 1 shows the TDIP area in pink and the projected expanded area of the sugar plantation in yellow.

\footnotetext{
${ }^{9}$ A new ruling as of September 2016 has revoked Tarda’s license, claiming the lease was unconstitutional (Botha 2016).
} 
Because numerous studies have been undertaken in the TDIP area, we use the area delineated by the original TDIP project (covering some 5,426 ha) as the system boundaries of our biomass calculations. Six villages are commonly associated with this TDIP Polder 1 area, with land falling within the traditionallydemarcated boundaries of three of these: Kulesa, Wema, and Hewani. These villages are incorporated into the project, while the other three villages - Vumbwe, Sailoni, and Baandi - border the project area, and have traditionally utilised 'common property' resources within it, and continue to do so, typically the floodplain forests and available grazing areas.

Figure 2 shows the land use in the TDIP area in 2005. In 1990 the population inside the TDIP was estimated at approximately 5,000 people, with a population growth rate of $13 \%$ every five years (HVA International 2007). All the villages are inhabited by Pokomo cultivators, with the exception of Baandi, which is inhabited by traditional Orma pastoralists.

\section{Results: the HANPP}

This section presents the livelihood strategies and biomass appropriation of two traditional villages in the TDIP area - one agriculturalist and one traditionally pastoralist, which currently also practices farming. The data, collected for the year 2010, demonstrates the diverse and contrasting ways in which the local communities appropriate biomass in the delta to sustain their livelihoods.

Patterns and capacity to harvest biomass are based on political economic and natural factors including relative prices of products, price elasticity for goods, market linkages, and ecosystem functioning, as well as changing scientific perceptions. For example, new scientific knowledge is recasting the impact of pastoralism, long considered damaging and underproductive, on drylands as policy fashions turn towards devolution in resource management and a growing recognition of the efficacy of communal tenure (Upton 2014). Success in harvesting biomass is linked to economic well-being. Apart from bringing differences between villages to light, the data also presents issues of productivity, incorporation in the market economy, food security, and dependency.

\section{Biomass use among the Pokomo}

Vumbwe is a Pokomo village, settled in the current location after the floods of 1961 and is composed of 20 Pokomo households (312 people) and seven Wata households (24 people). Eight Pokomo households and one Wata household were surveyed and average biomass use for a range of consumption activities were calculated per person in GJ, illustrated in Figure 3.

All the Pokomo families surveyed practised farming, with an average of 2.2-3 acres (approximately 1 ha) per family, ranging from half an acre to 4 acres ( 0.2 ha to 1.6 ha) per household. ${ }^{10}$ The primary crops include maize, cowpea and green-grams. The bulk of the harvest is for home consumption while a small percentage (10\%) is sold.

Two-thirds of households had a small number of chickens and 45\% had beehives. Almost all families also practiced fishing, with fish being an important source of protein in certain seasons. ${ }^{11}$ Two families used fish traps, which they left in the oxbow lakes, and sold fish. In Vumbwe, other livelihood strategies were charcoal-making (30\% of households), wage labour (30\%) and small businesses such as a local kiosk (30\%). No fertilisers were applied, but two families did use a small amount of pesticides on vegetable crops produced for sale only.

Two households practiced irrigation (with a diesel-powered pump) and owned generators while two others had solar panels. The remainder rely entirely on firewood (an average of 6 tons per household/yr) and

\footnotetext{
${ }^{10}$ The average for the Tana Delta district is 2 acres $(0.8 \mathrm{ha})$. Mean maize and rice yields for the area are approximately 1.3t/ha (Tana River District Development Plan 2002-2008).

${ }^{11}$ While we collected data on fish catch and fish purchases in the diet, we did not include this form of biomass because we did not measure the NPP of the lakes.
} 
charcoal for heating and cooking and paraffin for lighting. ${ }^{12} \mathrm{~A}$ third owned a bicycle and half of the households have a radio.

\begin{tabular}{|c|c|c|}
\hline Land use, midrange estimate & $\begin{array}{c}\text { Area } \\
\text { (ha) }\end{array}$ & $\%$ \\
\hline river & 94 & 2 \\
\hline bare/road & 124 & 2 \\
\hline flooded field & 107 & 2 \\
\hline open grass/shrub/crops & 1,254 & 23 \\
\hline open woodland/sparse tree & 1,746 & 33 \\
\hline shrubland & 487 & 9 \\
\hline woodland & 808 & 15 \\
\hline forest & 433 & 8 \\
\hline treed shamba & 288 & 5 \\
\hline Total Classified & 5,341 & 100 \\
\hline Uknown & 85 & 2 \\
\hline Total Area & 5,426 & \\
\hline
\end{tabular}

Figure 2: Land use in the TDIP (2005). Source: Glenday (2005).

Maize, the primary crop, is usually planted over half the field area, and often intercropped with cowpeas, with another half-acre ( $0.2 \mathrm{ha})$ of cowpeas and green-grams. Some households grow vegetables such as skuma (kale), tomatoes, onions, and bananas as cash crops. Average maize yields for 2009 were 1.5 tons of maize per ha (almost seven $90 \mathrm{~kg}$ bags per acre). This was considerably higher than the assertion from the EIA that local yields are of only 2-3 bags per acre (445-660 kg/ha) compared to up to 15 bags (over 3 tons/ha) in other parts of the country.

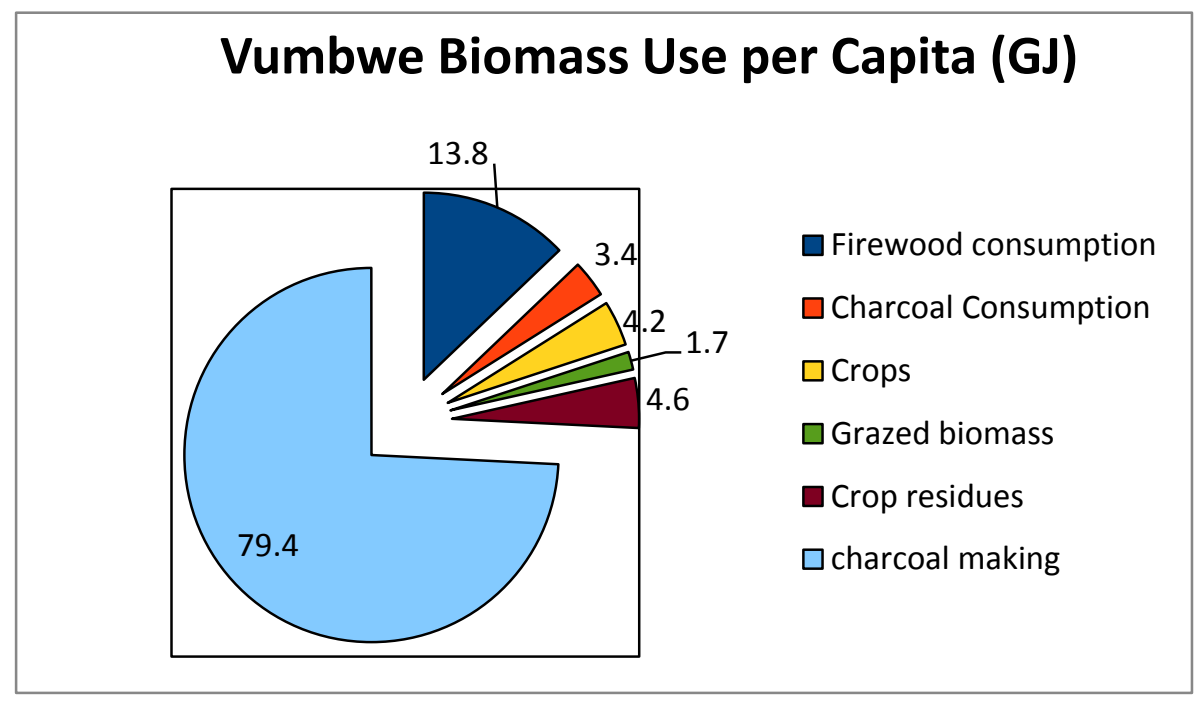

Figure 3. Vumbwe biomass use per capita. Source: original data.

\footnotetext{
${ }^{12}$ This is indicative of the district as a whole, in which $98.8 \%$ of households rely on charcoal or firewood.
} 
Most families have mango trees and sell the fruit, but many mangoes rot on the trees due to lack of marketing outlets. An average tree yields 100-400 mangos with an average weight of 570g per mango, for a total yield of between 3.4 to 13.6 tons/ha depending on the tree density. Women and young children in most families practice gathering of greens such as water lilies and other wild plants and a range of medicinal forest products. According to Medley (1993), the Pokomo make use of 98 plant species locally, accounting for 52\% of known species in the area.

Figure 3 demonstrates the biomass harvest per person in energetic units for the year 2009. Crops grown provided $4.2 \mathrm{GJ}$ of energy per year per person. While this is in line with food energy requirements per person $^{13}$, it means there is very little surplus available for sale to meet other needs. The crop consumption is supplemented with protein sources from fishing, small amounts of meat and some purchased products primarily rice, sugar, wheat flour, and oil.

Wood consumption represented 13.8 GJ per capita annually representing the most important element in direct consumption of biomass. However, the lion's share of extraction is attributed to the commercial production of charcoal, accounting for $75 \%$ of the harvest (80 GJ per person). Half of the households in Vumbwe produce charcoal for sale with an average of 40-60 (50 kg) bags per week being produced by the village, equivalent to 20 tons of wood extracted for charcoal per week. Charcoal is harvested in the delta primarily from along the floodplains where the tree growth is most lush. The Pokomo engage in this trade more than the Orma, particularly in seasons when the opportunity cost of labour is low (Ensminger 1984).

In Vumbwe village, there are 26 members of the Wata tribe who belong to one family, with 8 households between them. The Wata are the smallest and one of the most marginalised tribes in Kenya. They are traditionally hunter-gatherers. The male household head (49 years old) was the only one interviewee who engaged in every livelihood activity in the survey, including farming, livestock-keeping (goats), beekeeping, fishing, gathering, hunting, charcoal-making, business and wage labour (at Tarda). He produces from 5 to 20 bags of charcoal per week depending on demand. He estimated 30 minutes of work per $50 \mathrm{~kg}$ bag. Each bag sells for KSH 175 (US\$1.75), as an average between wholesale and market prices. Thus he can make KSH 87,500 (US\$869) annually for a declared 250 hours of labour - a return of KSH 350 (US\$3.47) per hour. According to the respondent, they continue to hunt large animals despite it being illegal, around one large mammal such as a hippo, giraffe, or buffalo per year. The meat is shared out among the hunters, with the surplus dried and sold in the village and surrounding areas.

\section{Biomass use among the Orma}

Baandi village is a community of 204 houses, comprising 1,000 people and the only Orma village within the TDIP. Baandi makes use of forest $64^{14}$ (124 ha), plus two others outside the project area, one to the north and one to the east of the village. The village has existed on a permanent basis in close proximity to Hewani village since 1988, after the villagers were forced to leave their previous permanent village, Gardeni, a few hundred metres further south, due to flooding. The Orma residents of Baandi distinguish themselves as being 'permanent' pastoralists within the Tana River delta and practice agriculture as well.

Among the Orma, cattle are the social representation of wealth and status and the basis of their social and cultural life. At the same time, increased sedentarization is leading to smaller herds, while wealth disparities mean there is considerable variation in cattle-holdings among the Orma. According to interviews with key informants and local district livestock officers, only 50-60\% of Orma own cattle. One household we interviewed had 500 head of cattle while another had none. It is difficult to ascertain whether self-reporting is accurate in either case, because counting cattle is said to bring bad luck. In Baandi the median was 15 head of

\footnotetext{
${ }^{13}$ According to the United Nations Food and Agriculture Organisation (FAO) an average adult male should consume food with an energy content of 3,200 kilocalories or $13.4 \mathrm{MJ}$ per day, while an average female should have 2,300 kcal or 9.63 MJ (Fisher and Bender 1975), In a year these figures come to 4.9 GJ and 3.5 GJ respectively, an average of about 4.2 GJ per year or $11.5 \mathrm{MJ}$ per day. In reality many consume significantly less than this amount.

${ }^{14}$ Forest numbers and names were proposed by Marsh (1986) in his survey of the Tana primates.
} 
cattle per household, the local Boran breed (an average of 72 due to the large variations among holdings). While other studies of herd size among the Orma estimate higher figures, such as 100 (Luke et al. 2005) and 124 (Irungu 2000) cattle per household, the lower median holdings in this village are likely due to their semisettled status. Households also have significant stocks of sheep and goats.

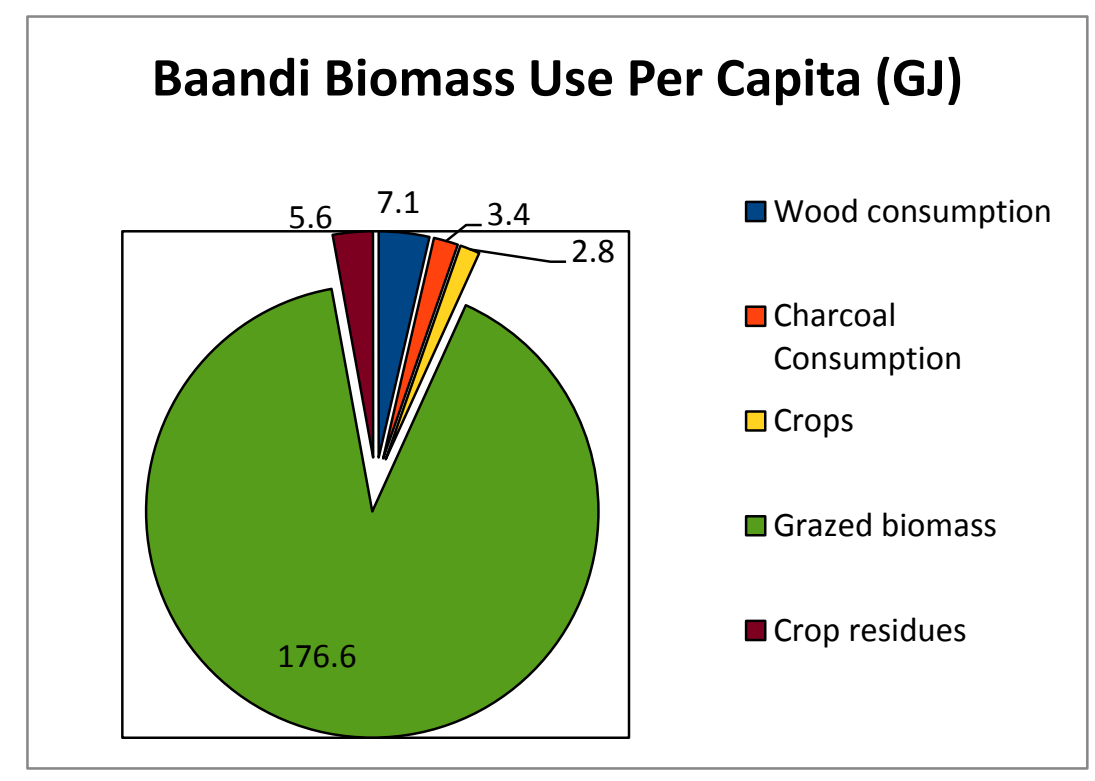

Figure 4: Baandi biomass use per capita, in gigajoules. Source: original data.

The Orma pastoralists of Baandi traditionally moved out of the flooded Tana delta during the long rains (March-April), utilising outlying grazing areas in the highlands until stocks are diminished and returning to the delta as the long dry-season progresses (August-September) to take advantage of the productive grasslands. They then remain in the delta until the following year's long rains return. However, as the rains and flooding have been reduced, they frequently keep their cattle in the delta all year long without moving them out (Lebrun et al, 2010).

Mean weight for a cow is $200-250 \mathrm{~kg}$. The Orma rarely slaughter their cattle, with the major product consumed locally being their milk. Cows produced a maximum of 5 litres of milk per day when grass is abundant. Milk provides about half a litre per person daily, which covers $20 \%$ of caloric needs, while the excess is shared or sold. Tana Delta District exports an average of 3,500 kg of meat and 2,500 l of milk, 1,000 head of cattle and 1,000 shoats (sheep and goats) monthly according to the district Livestock Officer. Approximately 4.7 million litres of milk were produced in the year 2000, with production peaking during the wet season (Irungu 2000).

Figure 4 shows the biomass harvest in GJ for Baandi village. It can be seen that grazing represents about $90 \%$ of the biomass harvest. In contrast, crops account for only $1.4 \%$. However, in energy terms crop production provides 2.8 GJ per capita per year, constituting an important share of the food requirement. While this emphasizes the important contribution of milk to meet further nutritional requirements it also shows how farming is still an important activity in terms of energy provisioning.

Another important flow for the local Orma is food aid, which in 2009 was distributed to 25\% of the population of the Garsen district. The Orma receive significantly more food aid than the Pokomo. According to the Red Cross, a total of over 143,223 Metric Tonnes of cereals, as well as pulses, oils, and blends, were distributed in 2009. A percentage of this is also for animal consumption. The allowance per person equals 2.5 GJ/per person/yr, representing almost 70\% of an average annual caloric intake of $3.5 \mathrm{GJ} /$ per person. 
Comparison of biomass between the two communities

Figure 5 shows the per capita biomass extraction (NPPh) per capita for the surveyed communities. A comparison reveals some unexpected and interesting dynamics. For example, while the area cultivated per $\mathrm{HH}$ is almost double in Vumbwe (1 ha/household), as compared to Baandi ( $0.6 \mathrm{ha} / \mathrm{household})$, reported yields for maize were significantly higher for Baandi (2,172 kg/ha) than for Vumbwe (1,446 kg/ha). One possible explanation for this is that while none of the respondents in Baandi reported using fertilisers or manuring, they did report that they graze their cattle in the fields after harvest to remove plant residues and they then leave the manure behind. Furthermore, the smaller area cultivated by the Orma may contribute to increased intensification per area.

\begin{tabular}{|c|c|c|c|c|}
\hline & \multicolumn{2}{|c|}{ Vumbwe } & \multicolumn{2}{c|}{ Baandi } \\
\hline & T/dm/cap/yr & $\%$ & T/dm/cap/yr & $\%$ \\
\hline Firewood and construction poles & 0.86 & $12.4 \%$ & 0.44 & $3.6 \%$ \\
\hline Charcoal Consumption & 0.21 & $3.0 \%$ & 0.21 & $1.8 \%$ \\
\hline Charcoal production for sale & 4.97 & $71.8 \%$ & 0 & $0.0 \%$ \\
\hline Wood Total & 6.04 & $87.2 \%$ & 0.65 & $5.4 \%$ \\
\hline Crop production & 0.26 & $3.8 \%$ & 0.17 & $1.4 \%$ \\
\hline Crop residues & 0.52 & $7.5 \%$ & 0.35 & $2.9 \%$ \\
\hline Crop total & 0.78 & $11.3 \%$ & 0.53 & $4.3 \%$ \\
\hline Grazed biomass & 0.1 & $1.4 \%$ & 11.04 & $90.3 \%$ \\
\hline Total & 6.9 & $100.0 \%$ & 12.2 & $100.0 \%$ \\
\hline
\end{tabular}

Figure 5: Biomass harvest (Tons of dry matter per capita), HANPPharv. Source: original data.

Also significant to note is that wood consumption is half as much in Baandi (440 kg/per person/yr) than Vumbwe (860 kg/pp/yr). This is attributed to the fact that the pastoralist diet is much more dependent on milk for calories and protein. The difference is even more significant due to the fact that the Orma use wood for house construction, with an average house comprising 1,100 twenty-five kg poles (Ensminger 1984), and for fences for cattle kralls (enclosures for cattle).

Seen as a whole, the largest percentage of total biomass extraction in the TDIP between the two communities (58\%) consists of grazed biomass to sustain cattle and shoats (sheep and goats). This demonstrates how in energetic terms, the pastoralist communities in the delta are able to harness considerably more of the flows of biomass from nature within the delta than those who practice only farming. Ruminants are able to convert this biomass into useful products for consumption, including meat, milk hides, and wool that may be represented in income. However, other flows benefit flows from cattle include their value as stores of wealth and social and cultural value for bride-wealth, loans, etc. While these values are not translated into monetary terms they do shed light into the underlying tensions feeding the antagonism between pastoralists and farmers in the delta.

Total biomass harvest for Vumbwe village was equivalent to 6.9 TDM or 107 GJ cap/yr (Figure 6). Omitting charcoal production and crop residues to see only flows consumed in the village, the per capita energy use is $1.68 \mathrm{TDM} 32.2 \mathrm{GJ} / \mathrm{cap} / \mathrm{yr}$. Total annual biomass harvest for Baandi per person is 12.2 TDM (equivalent to $195 \mathrm{GJ}$ ). Figure 6 provides a comparison between these figures and other HANPP per capita data. As Haberl et al. (2006) point out, a considerable range in national biomass harvest become even larger when we look at contemporary local studies: while the biomass consumption of Vienna, the capital of Austria, is only $7 \mathrm{GJ} / \mathrm{cap} / \mathrm{yr}$ (about twice the amount of food consumed by its inhabitants), rural villages in 
Austria such as Kottes may use as much as 215 GJ/cap/yr. Such high biomass consumption is explained by low population density leading to high per capita land availability.

\begin{tabular}{|c|c|}
\hline \multicolumn{2}{|c|}{ HANPP per capita (TDM) } \\
\hline Vumbwe & 6.9 \\
\hline Baandi & 12.2 \\
\hline EU15 & 2.86 \\
\hline US & 5.4 \\
\hline Kenya average & 5.94 \\
\hline Philippines 1920 & 11 \\
\hline Philippines 2000 & 2.8 \\
\hline
\end{tabular}

Figure 6: HANPP/Cap (TDM, Tonnes of Dry Matter). Source: elaborated from original data, Fetzel et al. (2016); Kastner et al. (2016) and Haberl et al. (2006).

\section{TARDA}

The Tarda project is the only commercial agriculture project in the Delta. Given the recent interest in investment, its progress is instructive. TARDA reclaimed an area in the upper Delta as part of its integrated rice project in the 1980s-1990s and continues to manage part of this land as a commercial farming operation.

In 2009, TARDA (Tani and Athi River Development Agency) rehabilitated a part of its project destroyed by the El Niño floods, with a KSH 400 million (US\$3.97 million) economic stimulus program from the government. The project was operated as an 'estate system' with all production, harvesting and sales etc. carried out by the TDIP central office, while the community members conducted weeding, bird- and wildlife-scaring, etc. through casual labour contracts. TARDA planted 550 acres (223 ha) of land with maize under a rainfed system, with the intent to make the transition to rice cultivation. The yield was extremely low at only 5.6 bags $(90 \mathrm{~kg})$ per acre $(1,295 \mathrm{~kg} / 18.5 \mathrm{GJ} / \mathrm{ha})$.

The TARDA production manager interviewed attributed this to low rainfall and the wrong seed being delivered, and pointed out that in the current season in 2010, yields were triple the previous season. Fertiliser, Diammonium Phosphates (DAP) was applied at the rate of $100 \mathrm{~kg} / \mathrm{ha}$, as well as pesticides. Approximately 400-500 people were employed monthly, primarily as 'scarers' (dissuading wild animals from eating their crops) during the harvest season, at a rate of KSH 250 for an 8-hour day (US\$2.48). ${ }^{15}$ While the yields were from 2.5 to 4 times the magnitude of those achieved by the Pokomo and Orma farmers, respectively, the maize grown by TARDA in 2009 never made it to market as it was. The maize was meant to be delivered to the National Cereals Board but was improperly dried in storage and developed Aflatoxins and had to be discarded. The low yields, falling well short of the performance that would be required in a non-subsidised commercial operation, as well as the marketing issues confronted, do point to the mismatch between projected productivity and actual productivity in large-scale operations. In 2016, The High Court in Malindi revoked Tarda's 45-year lease for 25,875 hectares of Tana Delta Irrigation Project land following a petition by the Tana River County Government, based on claims that Tarda used unconstitutional means to acquire the land (Botha 2016).

\section{Discussion}

In the previous section we examined the varying uses of biomass among communities. This gives us a clear picture of current resource uses and the most significant flows. The following section discusses some of

\footnotetext{
${ }^{15}$ The project manager informed me, however, that their jobs would soon become obsolete as they would be installing an electric fence in 2011.
} 
the implications for this biomass distribution and HANPP, if the Mumias TISP project is to proceed and the TDIP were to be converted to industrial sugar production.

To get a picture of changing biomass distribution among users in the current scenario and in the sugar scenario in the TDIP area, HANPP data from global series (available in a $10 \mathrm{~km} \times 10 \mathrm{~km}$ scale) elaborated by Haberl et al. (2007a) can be applied to the different land use types in the TDIP (as described in Figure 2).

Data from the global study estimates actual NPP across these different land uses, which range from $13 \%$ on grasslands to $57 \%$ on cropland. Crossing the data from the global study for the TDIP area (Figure 7) with that on Land Use in the TDIP (Figure 2) gives us an average HANPP of 26\% in the area. Assuming that that the land allotted to TARDA within the TDIP area (4,046 ha), minus the land that is currently built-up (124 ha) or forest and woodland (1,241 ha) is cleared and turned over to sugarcane, the first significant change would be drastically increased biomass production. Assuming that the yields projected in the project plan of 150 tons of cane per ha are achieved (equivalent to 69 tons of dry matter per hectare each year), this would mean increased biomass production, from a current 26,240 TDM within the 5,426 ha of the TDIP to NPP of over 185,000 TDM - an increase in NPP of above ground (ABG) biomass production of almost 8 times over previous levels, due to inputs such as fertilisers and irrigation.

\begin{tabular}{|l|r|r|r|}
\hline & NPPact & Npph & HANPP(H) \\
\hline Forest & 5.2 & 1.2 & $24 \%$ \\
\hline Cropland & 3.1 & 1.7 & $57 \%$ \\
\hline Built-up & 2.5 & 1.3 & $50 \%$ \\
\hline Potential Grazing & 5.1 & 0.7 & $13 \%$ \\
\hline
\end{tabular}

Figure 7: HANPP per ha per year (TdM) values for the TDIP area from the global database (Haberl et al. 2007).

The current HANPP shows that currently only $26 \%$ of biomass is being appropriated. In the sugar scenario, while biomass production will increase considerably, harvest will also increase. On cropland currently, only 56\% of biomass is harvested (Fig. 7), compared to global average HANPP intensity on cropland of $83.5 \%$ (Haberl et al. 2007a). Given that the TISP plans to process crop residues, we can assume that the HANPP under sugar-cane would be upwards of $90 \%$. This would translate to a total HANPP of the TDIP area upwards of $80 \%$, leading to considerable transformation of the territory and biomass flows unavailable for other users. It should be noted that the entire area of the projected TISP project is 22,000 ha and land use changes in this entire area would lead to similar dynamics.

Calculating the new HANPP distribution between the Pokomo, Orma, and other communities in the scenario would be mostly speculative and it is not my intention to do so here, however the historical record provides illustrative examples of the social and environmental impacts that decreased biomass from the reduction of flooding in the delta as a result of dams upstream have had. This includes reduction in herd size, adaptive strategies such as diversification of livelihood activities (to farming, day-labour and others), and also increased conflict between communities for increasingly scarce biomass and related eco-system services.

Calculating future HANPP would also need to take into account complex feedback mechanisms associated with increased biomass extraction, such as land and forest degradation and the impact of increased sedentarization. Regarding forest pressure, the EIA estimates that due to population growth alone, ${ }^{16}$ an additional demand of 1 million kg of fuelwood per year will be needed across the entire project area (HVA 2007). This figure should be considerably higher due to the projected influx of settlers. Furthermore, charcoal

16 Population growth in the Tana Delta District is $3.4 \%$ annually. 
harvesting will probably increase as the Pokomo seek ways to complement seasonal income from labour in the plantations. Unless a forestry component is put into place, the result will inevitably be "...developmentinduced desertification spread as concentric rings around the schemes" (Johansson 1991;116) and conflict between the traditional population and new migrant workers.

Also not considered are the wider impacts beyond the project area. For example, the settling of nomadic pastoralists leads to dietary changes and consequent changes in wood and biomass use. Ensminger (1984) established that the degree of sedentarization has a direct effect on fuel consumption. She attributes this to the fact that the area around permanent settlements is quickly overgrazed and as livestock produce less milk, pastoral households are increainsgly drawn into the market economy to purchase foodstuffs. She establishes that the change in diet from milk to cooked grains and (heavily sugared) tea leads to heavily increased use of fuelwood.

Another question as regards the HANPP is related to the relative sustainability of local practices of livestock grazing and charcoal burning. While local reliance on traditional breeds is considered unproductive and large herds are viewed as the result of the pastoralists' 'irrational' attachment to their animals rather than economic gain, a study of the Borana system in Ethiopia found it very productive compared with Australian commercial ranches: the Borana produced nearly four times as much protein and six times as much food energy per hectare. Their major concern was not the number of cows owned, but the number of people supported by the rangeland (Cossins 1984).

Moreover, the effect of grazing on grassland productivity and grazed ecosystems is generally not well understood. Studies show that grazing may either enhance ('compensatory growth') or reduce productivity ('degradation') (Haberl et al. 2010). Analyses demonstrating the proportion of annual primary production available to livestock and the proportion actually consumed, combined with the tolerance levels of different plant communities to exploitation, are called for to understand the impacts of pastoral land uses.

Although commercial charcoal production on public lands has been illegal in Kenya since 1986 as an effort to curb deforestation, enforcing this ban is difficult in a country where $85 \%$ of the population depends on charcoal. In 2002 the government estimated that 2.4 million tons were consumed countrywide. Here different contrasting environmental narratives can be heard from the state and local users. According to local charcoal-makers, the trees they burn were cut by TARDA when clearing land and, being too large to be collected, would otherwise rot in situ. While charcoal is decried as wasteful, its energy return on energy input (EROEI) seems favourable when compared to that of biofuels. While 60\% of the original energy is lost in the conversion process from wood to charcoal, the resulting fuel has almost twice the energy of the parent material $^{17}$, is less polluting, and is more convenient to use and cheap to transport. By contrast, for electrical generation from fossil fuels, up to $75 \%$ of the energy may be lost in production and distribution.

\section{Backflows to nature and biodiversity}

The flows of energy and nutrients in the delta demonstrate how the balance between different land uses is a crucial element in the maintenance of socio-environmental stability as interactions between multiple uses of nature contribute to increased productivity (Cusso, Garrabou and Tello 2006; Hamerlynck et al. 2010). As a means of insuring against the constant threat of drought, famine, epidemics, and stock-raids, the communities have developed inter- and intra-communal as well as external linkages. Shifts in pastoral land use practices - adoption of cultivation, abandonment of nomadism, permanent settlement, and landscape fragmentation - will inevitably affect the distribution and diversity and viability of nutrients, vegetation, biodiversity, and landscapes in ecosystems. Backflows into the system, such as manure, create nutrient cycles that improve biodiversity. Farmers also benefit through increased soil fertility that is distributed during the annual flooding and that contributes to the high productivity of floodplain agriculture.

\footnotetext{
${ }^{17}$ Charcoal typically has a calorific value of 32-33 MJ/kg, compared to the original wood's value of $18-19 \mathrm{MJ} / \mathrm{kg}$, however significant energy losses occur in the process of transformation.
} 
A decrease in wildlife also has important implications for NPP. The town of Moa in the Delta has an oxbow lake that supports 300 Luo fishermen, largely due to nutrient flows from hippos and their mineral rich dung which favours an increase in aquatic plant and fish production (Marchand 1987). MEFA and HANPP analysis provide a tool for tracking the cycles of residues and wastes that are not direct inputs to the economic system but provide valuable services.

It also provides a cautionary note to the development of cellulosic technologies that will permit the use of crop residues for biofuel generation. Removal of such 'waste' residues from the field should consider their role in maintaining soil organic matter levels and preserving or enhancing productivity. This highlights the importance of improving the efficiency of biomass appropriation by reducing land use-induced productivity losses rather than backflows to nature, because the latter may have considerable ecological benefits (Fetzel et al. 2016).

Some articles have explored the relationship between NPP and biodiversity (Haberl et al. 2007b). The species-energy hypothesis states that the number of species is positively related to the flow of energy in an ecosystem, although a direct correlation has not been firmly established (Wright 1983). A certain level of NPP can be considered a necessary, but not sufficient, condition for the maintenance of certain types of biodiversity. As the HANPP increases, biodiversity as a whole declines, leading Vitousek et al. (1986) to propose HANPP as an indicator of pressure on biodiversity. However, plant diversity as well as total biomass are both important drivers, particularly for species that are as specialized in their diets as the Red Colobus Monkey for example. While the Colobus do not consume human food, they are an edge species, preferring forest margins over mature forests and only eating certain leaves. Similarly, the semi-terrestrial Tana Mangabey (an endangered primate), is well adapted to a landscape mosaic with alternating fields, forests, and bush (Hamerlynck et al. 2010).

\section{Conflicts, alliances and resistances over biomass}

In August 2012, the long-running conflict between Orma and Pokomo broke out once again with over one hundred people and hundreds of cattle massacred. The fighting was attributed to conflict over grazing land, but also to the increasing value of the delta's resources and increasing demands by local, national, and international investors for land in the Tana Delta. ${ }^{18}$ The HANPP data presented sheds light on the dynamics of this conflict and the differing positions amongst farmer and pastoralists communities towards large-scale agricultural projects generally. As demonstrated, the Orma have significantly more to lose in terms of access to biomass than the Pokomo.

Pastoralists are particularly vulnerable to sugarcane and biofuel development, and the possible growth of the bio-economy. This is because they occupy the marginal and 'waste' lands that are being targeted by crops such as Jatropha, as well as the irrigable dry-season grazing areas favored for sugarcane plantations. Governments are also seizing this opportunity to encourage more intensive cattle-raising with imported breeds, simultaneously achieving goals of settling nomadic communities dependent on grazing (Scott 1998) and increasing the presence of the state in frontier regions (Kajwanga 2003). As a result, in many places, pastoralism is under threat of losing significant land area to other forms of resource use, which are perceived by governments to be more productive.

One of the lasting impacts of conservation in the Tana Delta has been the creation of deep resentment from the local communities against development and conservation projects, and their implementing agencies such as TARDA and KWS (Hamerlynck et al. 2010). The TRPR case is representative of the often opposing positions of conservationists and local communities in Africa. Historically, conservationist groups have been critical of overgrazing and overstocking of cattle by pastoralists. The antagonism between pastoral communities towards environmentalists can also be attributed to the fact that in East Africa, wildlife conservation has robbed pastoralists of a significant part of their traditional rangelands. Pastoralist survival strategies create ecosystems well-suited to grazing ecology, and herders have never subdivided savannah

\footnotetext{
${ }^{18}$ http://allafrica.com/stories/201208250194.html
} 
rangeland (Homewood and Rogers 1991). As a result, pastoralists are now surviving on a small fraction of their traditional grazing land and are highly critical of attempts by conservation interests to claim the remaining pastures for wildlife preservation (Cooke 2007). However, in the current situation we are beginning to see strategic alliances appearing. In the fight against the sugar company, environmentalists and pastoralists have entered into a temporary marriage of convenience. Two streams of environmentalism have aligned for mutual benefit: the cult of 'wilderness' collaborating with the "environmentalism of the poor" (Guha and Martinez-Alier 1997). Significant victories have been achieved through this alliance; in this case a key actor has been Nature Kenya, the Kenyan branch of the East African Natural History Society and the oldest conservation organisation in Africa. In 2012, the Tana River Delta was designated one of the newest Ramsar (The Convention on Wetlands) sites in Africa. In 2014, the organisation in coordination with the Office of the Prime Minister, helped produce a land use plan aiming to lead to the long-term sustainable management of the Tana River Delta in consultation with local people and all interested parties to safeguard local livelihoods and wildlife, while permitting sustainable development projects in designated areas (Odhengu et al. $2014^{19}$ ).

\section{Data limitations and future research}

HANPP calculations suffer from constraints regarding data availability, which mean that the results of this study should be considered as estimates. For example, the data from the global HANPP study is taken from the FAO database (FAO 2011d) where data quality is not uniform across countries. Further, while the scenario is illustrative, it should be kept in mind that the level of analysis covers a relatively small area of only 5,000 ha. Some challenges in doing such calculations include the difficulty of accounting for all livestock movement in and out of system boundaries. For simplicity we count only the livestock resident within the boundaries although they are of course prone to graze elsewhere, and external cattle also graze within. Secondly, it is not feasible to establish all the possible environmental and land changes induced through plantation expansion and the scenario should be viewed as a way to illustrate how the methodology could be applied with an initial base-line study, and after land transformation.

Further research on actual and potential biomass distribution at the scale of the entire delta area, building on the work here, would provide further insights into the potential impacts of land-grabbing in regions that are not yet part of global biomass trade flows but are being targeted. The delta has been targeted for the establishment of two (now defunct) biofuel projects including Bedford Biofuels from Canada (50,000 ha) and G4 Industries from the UK (28,000 ha), which would have significantly reduced grazing land on the banks of the river surrounding the delta and thus potentially further increasing pastoralist pressure on the central wetlands. Should these, or other new projects become operational, they will result in increased extraction of water, which will further upset the flooding regime and may reduce the flows necessary to the survival of the riverine forests in the delta - and to the floodplain fertility and productivity, the source of sustenance for farmers and pastoralists. This would lead to further transformations of the remaining areas and land productivity, with consequent social and ecological feedback processes that cannot be predicted.

Another fruitful avenue for future research concerns the relationship between HANPP and water availability, the primary limiting resource in the delta. The specific ways in which water underpins land productivity in the semi-arid and sub-humid African savannahs needs to be better understood, particularly due to the impacts upon existing local water resource users. ${ }^{20}$ Further research could also complement biomass accounts with virtual water export calculations, as the land grab is concurrently a water grab. While a report from the World Bank explicitly states that its estimates of farmland 'available' for investment are based on suitability for rainfed production alone (Deininger and Byerlee 2010), a review of land deal contracts by Cotula (2011) makes the point that land leases in semi-arid countries would be worthless if they did not ensure access to sufficient irrigation water..

\footnotetext{
${ }^{19}$ The data from a previous version of this article here was used extensively in this land use plan.

${ }^{20}$ See work by Duvail et al. (2012) and Leathaud et al. (2013) for good examples of such studies.
} 
While energetic and material flow analysis can give a perspective on productivity and efficiency not reflected in purely monetary analyses, limitations of biophysical indicators begin to express themselves. MFA data does not offer an integrated analysis of the local economy: economic, political, and cultural elements cannot be expressed in tons of dry matter. Moreover, biophysical data is not a clear indication of the sustainability of extractive and agricultural flows. The relationship between more biomass and other measures of sustainability/livelihood impacts is not linear. Just as the correlation between species diversity and HANPP is difficult to gauge because HANPP may favour some species at the expense of others; this paper has shown how contrasting uses of HANPP will favour some groups at the expense of others.

\section{Conclusion}

The acquisition of land by foreign land users, either through land leases or land purchases, is leading to the creation of new geographies of investment, production, and consumption and the displacement of environmental burdens. This spatial displacement has been termed 'tele-connection', defined as "the correlation between specific planetary processes in one region of the world to distant and seemingly unconnected regions elsewhere" (Haberl et al. 2009:120).

Land use indicators such as HANPP are increasingly used to examine the biophysical limits of 'feeding the world' and this allows an approximation for the question of whether massive quantities of biomass can be harvested sustainably without eroding and degrading soils, destroying biodiversity, increasing food insecurity, and disrupting the livelihoods of marginalised peoples. The contribution of this article has been to highlight how socio-metabolic indicators such as HANPP can also shed insight into the political ecology of power relations in the delta, and how power and ability to appropriate nature interact.

In the Tana Delta today the biomass appropriated by humans remains largely within the area, except for the charcoal sold to traders and some meat exports and cash crops, such as mangoes and bananas. In a future sugar economy, biomass production would increase, the proportion appropriated by humans would increase even more, the Orma and the Pokomo would be dispossessed, less biomass would be available for local 'wild' biodiversity, and a much larger proportion of the NPP would be exported as sugar or ethanol or even as electricity produced from bagasse.

Increased production of biomass means more productivity, but it does not mean more for everyone among the human species and across species. The re-assignation of rights to biological productivity and the incorporation of farmers and pastoralists into new agrarian structures transforms not only social relations and accumulation strategies, but it also reproduces nature with profound impacts on ecosystem energetics and corresponding livelihood strategies. The article has focused on changes in biomass production and use in the Tana Delta as an inquiry into the question of biomass for whom, and at what environmental cost. Many of the internal social conflicts can be interpreted in the light of studies of social metabolism, bridging the divide between ecological economics and political economy in a new political ecological economics. Political ecologists have made the case for a political ecology that better integrates biophysical ecology (Walker 2005). Similarly, ecological economics frameworks such as MEFA, situated at the interface of society and nature interactions, can be brought to bear to analyze power dynamics and ecological distribution conflicts as this article has demonstrated.

The World Bank Land Grabbing report (Deininger and Byerlee 2010) includes much of Sub-Saharan African in a "suitable land available, high yield gap" category, arguing that cultivation in these areas could be massively intensified. Under Deininger and Byerlee's logic, closing the yield gap through transfer of land to more "efficient users" (efficiency being measured in economic terms, disregarding the EROI) is the answer to the scramble for biomass resources. This paper has attempted to delve into some of the impacts on human livelihoods and biodiversity conservation at a local scale that such transfers will entail.

Further, the results call into question the barometer of 'productivity' as defined by the World Bank and similar studies, based on monoculture and simplified energy-material relationships rather than on multi-use relations with complex feedback processes and complementarities. Data shows that pastoralism, long considered an 'underproductive' activity may be the most profitable and beneficial means of biomass appropriation 
in certain environmental contexts. The concept of the yield gap denies that existing land use may well be the most productive, equitable, and sustainable, and that increased yields and intensification come at the cost of externalities and decreased energy efficiency. The provisioning ecosystem services of increased productivity (food, fibre, and fuel provisioning for the global market) come at the expense of other environmental services not valued by the market. Furthermore, grand schemes to transform the African bush into bountiful Edens consistently ignore the embarrassing failures of past experiences.

Further research is needed into the distributional impacts of changes in the distribution of biomass at local and global scales that land-grabbing will lead to, as are analyses combining biophysical, economic, political-ecological, cultural, and geographical theories of land use that can elucidate trade-offs between local human subsistence needs, biomass availability for other species, carbon sequestration, bio-energy production, and biodiversity, as well as trade-offs between productive and other, ecosystem services transferred spatially through biomass trade (Haberl et al. 2010). Who gets the HANPP in the end is a political question, not only one concerned with bio-capacity and sustainable limits.

\section{Bibliography}

Andersen C.B., R.K. Donovan and J.E. Quinn. 2015. Human Appropriation of Net Primary Production (HANPP) in an agriculturally-dominated watershed, Southeastern USA. Land 4: 513-540.

Andrews, P. 1975. Ecology of the Lower Tana River Flood Plain (Kenya). Journal of the East African Natural History Society and National Museum 151: 1-31.

Anonymous. 2009. Grow your own. The Economist June 19. http://www.economist.com/node/11565647

Bernstein, H. 2007. Rural livelihoods in a globalising world: bringing class back in. Conference on policy intervention and rural transformation: towards a comparative sociology of development, China Agricultural University, Beijing, 10-16 September 2007.

Bocha, G. 2016. State firm Tarda loses ownership of 25,875-hectare land in Tana River. Daily Nation. Sept. 21.

Coase, R.H. 1960. The problem of social cost. In Gopalakrishnan, C. (ed.). Classic papers in natural resource economics. Palgrave Macmillan. Pp. 87-137.

Cooke, A. 2007. Subdividing the savannahs: the ecology of change in Southern Tanzania, Doctoral dissertation, University of North Carolina.

Cossins, N.J. 1984. The productivity and potential of pastoral systems. Ethiopian Rangelands Programme, paper presented at the International Rangelands Congress, Adelaide, Australia, May 1984.

Cotula, L. 2011. Land deals in Africa: what is in the contracts? London: International Institute for Environmental and Development.

Cussó, X., Garrabou, R. and E. Tello. 2006. Social metabolism in an agrarian region of Catalonia (Spain) in 1860-1870: flows, energy balance and land use. Ecological Economics 58(1):49-65.

Deininger K. and D. Byerlee, with J. Lindsay, A. Norton, H. Selod, and M. Stickler. 2010. Rising global interest in farmland: can it yield sustainable and equitable benefits? Washington DC: World Bank.

Duvail, S., C. Médard, O. Hamerlynck and D.W. Nyingi. 2012. Land and water grabbing in an East African coastal wetland: The case of the Tana delta. Water Alternatives 5(2): 322-343.

Ensminger, J. 1984. Monetization of the Galole Orma economy: changes in the use of fuel and woodstock. In C. Barnes, J. Ensminger, and P. O'Keefe (eds). Wood energy and households: perspectives on rural Kenya. Uppsala: The African Institute.

Ensminger, J. and A. Rutten. 1991. The political economy of changing property rights: dismantling a pastoral commons. American Ethnologist 18(4): 683-699.

Erb, K-H., F. Krausmann, W. Lucht and H. Haberl. 2009. Embodied HANPP: mapping the spatial disconnect between global biomass production and consumption. Ecological Economics 69: 328-334. 
ETC Group. 2010. The new biomasters: synthetic biology and the next assault on biodiversity and livelihoods. ETC Group Communiqué \# 104. ETC Group.

Fetzel, T., M. Niedertscheider, H. Haberl, F. Krausmann and K-H. Erb. 2016. Patterns and changes of land use and land-use efficiency in Africa 1980-2005: an analysis based on the human appropriation of net primary production framework. Regional Environmental Change 16(5): 1507-1520.

Fischer-Kowalski, M. and H. Haberl. 2012. Metabolism and colonization: modes of production and the physical exchange between societies and nature. Innovation: European Journal of Social Science Research 6(4): 415-442. Academia

Fisher, P. and Bender, A.E., 1975. The value of food. Oxford: Oxford University Press.

Frow, E., D. Ingram, W. Powell, D. Steer, J. Vogel and S. Yearly. 2009. The politics of plants. Food Security 1: $17-23$.

Glenday, J. 2005. Preliminary assessment of carbon storage and the potential for forestry based carbon offset projects in the Lower Tana River forests: the Tana Delta Irrigation Project and the Tana River National Primate Reserve. Unpublished report to the Critical Ecosystem Partnership Fund. http://cepf.tfcg.org/downloads/Tana_Carbon_Study.pdf (accessed Oct. 2016).

GRAIN 2008. Seized: the 2008 land-grab for food and financial security. https://www.grain.org/article/entries/93-seized-the-2008-landgrab-for-food-and-financialsecurity (accessed Oct. 2016).

Guha, R. and Martinez-Alier, J. 1997. Varieties of environmentalism: essays North and South. London: Earthscan.

Haberl, H. 1997. Human Appropriation of Net Primary Production as an environmental indicator: implications for sustainable development. Ambio 26(3): 143-146.

Haberl, H., K-H. Erb, and F. Krausmann. 2014. Human appropriation of net primary production: patterns, trends, and planetary boundaries. Annual Review of Environment and Resources 39: 363-391.

Haberl, H., K-H. Erb, and F. Krausmann. 2010. Global human appropriation of net primary production (HANPP). In Cutler J.C. (ed.) Encyclopedia of Earth. Washington, DC: Environmental Information Coalition, National Council for Science and the Environment. Last revised April 29, 2010. www.eoearth.org (Site was down, Nov. 2016)

Haberl, H., K-H. Erb, F. Krausmann, S. Berecz, N. Ludwiczek, J. Martínez-Alier, A. Musel and A. Schaffartzik. 2009. Using embodied HANPP to analyze teleconnections in the global land system: conceptual considerations. Danish Journal of Geography 109(2):119-130.

Haberl, H., K-H. Erb, F. Krausmann, V. Gaube, A. Bondeau, C.Plutzar, S. Gingrich, W. Lucht, and M. Fischer-Kowalski, M. 2007a. Quantifying and mapping the human appropriation of net primary production in earth's terrestrial ecosystems. Proceedings of the National Academy of Sciences 104: 12942-12947.

Haberl, H., K-H. Erb, C. Plutzar, M. Fischer-Kowalski, and F. Krausmann. 2007b. Human appropriation of net primary production (HANPP) as indicator for pressures on biodiversity. Ecological Questions 8: 25-36.

Haberl, H., H. Weisz, C. Amann, A. Bondeau, N. Eisenmenger, K-H. Erb, M. Fischer-Kowalski and F. Krausmann. 2006. The energetic metabolism of the European Union and the United States: decadal energy input time-series with an emphasis on biomass. Journal of Industrial Ecology 10(4):151-171. Researchgate

Haberl, H., M. Fischer-Kowalski, F. Krausmann, J. Martinez-Alier and V. Winiwarter. 2011. A sociometabolic transition towards sustainability? Challenges for another Great Transformation. Sustainable Development 14: 1-14. Researchgate

Hamerlynck O., J. Nyunja, Q. Luke, D. Nyingi, D. Lebrun and S. Duvail. 2010. The communal forest, wetland, rangeland and agricultural landscape mosaics of the Lower Tana, Kenya: a socio-ecological entity in peril in Sustainable use of biological diversity in socio-ecological production landscapes. 
Background to the Satoyama Initiative for the benefit of biodiversity and human wellbeing. Secretariat of the Convention on Biological Diversity, Montreal. Technical Series 52: 54-62. [Available online www.cbd.int/database/attachment/?id=340]. Accessed March 2012.

Hamerlynck O., Q. Luke, T.M. Nyange, S. Duvail and C. Leauthaud. 2012. Range extension, imminent threats and conservation options for two endangered primates: the Tana River Red Colobus Procolobus rufomitratus rufomitratus (Peters, 1879) and the Tana River Mangabey Cercocebus galeritus (Peters, 1879) in the Lower Tana Floodplain and Delta, Kenya. African Primates 7(2): 211217.

Homewood, K. and Rogers, W.A. 1991. Maasailand ecology: pastoral development and wildlife conservation in Ngorongoro, Tanzania, Cambridge: Cambridge University Press.

Horta, K. 1994. Troubled waters: World Bank disasters along Kenya's Tana River. Multinational Monitor. July 1, 1994. http://www.multinationalmonitor.org/hyper/issues/1994/08/mm0894_08.html (accessed Oct. 2016)

Hughes, F.M.R. 1984. A comment on the impact of development schemes on the floodplain forests of the Tana River of Kenya. The Geographical Journal 150: 230-244.

Hughes, F.M.R. 1990. The influence of flooding regimes on forest distribution and composition in the Tana River Floodplain, Kenya. The Journal of Applied Ecology 27: 475-491.

HVA International 2007. Tana Integrated Sugar Project EIA study report. http://www.dlistasclme.org/sites/default/files/doclib/MUMIAS_Tana_EIA_part1.kenya_0.pdf (accessed Oct. 2016).

Imhoff, M.L., L. Bounoua, T. Ricketts, C. Loucks, R. Harriss and W.T. Lawrence. 2004. Global patterns in human consumption of net primary production. Nature 429: 870-873.

Irungu, P. 2000. Cattle keeping practices of the Orma people, a household survey in Tana River District, Kenya. Ketri-Ilri Collaborative Study.

Johansson, S. 1991. Ecological implications for Tana River Basin forestry and irrigated agriculture. In P. Trevor and W. Baxter (eds). When the grass is gone: development intervention in African arid lands. Uppsala: Scandinavian Institute of African Studies.

Kagwanja, P.M. 2003. Globalizing ethnicity, localizing citizenship: globalization, identity politics and violence in Kenya's Tana River Region. Africa Development XXVIII. 1 \& 2: 112-152.

Kastner, T., K-H. Erb and F. Krausmann. 2016. The Philippines 1910-2003: a century of transitions. In Haberl H., M. Fischer-Kowalski and F. Krausmann (eds.). Social ecology: society-nature relations across time and space. Springer International Publishing. Pp. 447-458.

Krausmann, F., Erb, K.H., Gingrich, S., Haberl, H., Bondeau, A., Gaube, V., Lauk, C., Plutzar, C. and Searchinger, T.D., 2013. Global human appropriation of net primary production doubled in the 20th century. Proceedings of the National Academy of Sciences 110(25): 10324-10329.

Krausmann, F., K-H. Erb, S. Gingrich, C. Lauk and H. Haberl. 2008. Global patterns of socioeconomic biomass flows in the year 2000: a comprehensive assessment of supply, consumption and constraints. Ecological Economics 65: 471-487. Academia

Leauthaud, C., S. Duvail, O. Hamerlynck, J.L Paul, H. Cochet, J. Nyunja, J. Albergel and O. Grünberger. 2013. Floods and livelihoods: the impact of changing water resources on wetland agro-ecological production systems in the Tana River Delta, Kenya. Global Environmental Change 23(1): 252-263.

Lebrun, D., O. Hamerlynck, S. Duvail and J. Nyunja. 2010. The importance of flexibility: an analysis of the large-scale Tana Delta irrigation project in Kenya, implemented under an estate system. In B. Calas and C.A. Mumma Martinon (eds.) Shared water, shared opportunities: hydropolitics in East Africa. Nairobi: IFRA and Hekima College. Pp. 261- 282.

Luke, Q., R. Hatfield and P. Cunneyworth. 2005. Rehabilitation of the Tana Delta Irrigation Project, Kenya: an environmental assessment. Unpublished report to the Critical Ecosystem Partnership Fund. http://www.cepf.net/Documents/Final.TDIP_Environmental_Assessment.pdf (accessed Oct. 2016). 
M'Gonigle, R.M. 1999. Ecological economics and political ecology: towards a necessary synthesis. Ecological Economics 28: 11-26.

Machuhi, E. 2010. World Bank ordered to pay villagers Sh634 Million for land. Daily Nation. 19 April

Marchand, M. 1987. The productivity of African floodplains', International Journal of Environmental Studies 29: 201-211.

Marsh, C.W. 1986. A survey of Tana River primates and their habitat. Primate Conservation 7:72-82.

Martinez-Alier, J. 2002. The environmentalism of the poor: a study of ecological conflicts and valuation. Cheltenham: Edward Elgar. Ch.1, 2

Medley, K.E. 1993. Extractive forest resources of the Tana River national primate reserve, Kenya. Economic Botany 47: 171-183.

Mireri, C., J. Onjala and N. Oguge. 2008. The Economic Valuation of the Proposed Tana Integrated Sugar Project (TISP), Kenya. Report for Nature Kenya. Mimeo.

Moore, J.W. 2009. Ecology and the accumulation of capital: a brief environmental history of neoliberalism. Lund: Department of Human Geography, Lund University.

Moore, J.W. 2000. Environmental crises and the metabolic rift in world-historical perspective. Organization and Environment 13(2): 123-158.

Mugambi, K. 2009. Mumias seeks to unlock Sh30 billion Tana Delta Funds. The Nation 18 July.

Odhengo, P., P. Matiku, J. Nyangena, K. Wahome, B. Opaa, S. Munguti, G. Koyier, P. Nelson, E. Mnyamwezi and P. Misati. 2014. Tana River Delta land use plan baseline report. Nairobi: Kenyan Ministry of Lands, Physical Planning Department.

Okoth-Ogendo, H.W.O. 1991. Tenants of the crown: evolution of agrarian law and institutions in Kenya. Nairobi: ACTS Press, African Centre for Technology Studies.

Running, S.W. 2014. A regional look at HANPP: human consumption is increasing, NPP is not. Environmental Research Letters 9(11): 111003.

Schandl, H., C. Grubunhel, H. Haberl and H. Weisz, 2002. Handbook of physical accounting: measuring biophysical dimensions of socio-economic activities: MFA-EFA-HANPP. Working Paper 73. Vienna: Institute for Social Ecology.

Sieferle, R. 2001. The subterranean forest: energy systems and the Industrial Revolution. Cambridge: White Horse Press.

Singh, J. and C.M. Grünbühel. 2003. Environmental relations and biophysical transition: the case of Trinket Island. Geografiska Annaler: Series B, Human Geography 85: 191-208.

Singh, S.J., F. Krausmann, S. Gingrich, H. Haberl, K.H. Erb, P. Lanz and L. Temper. 2012. India's biophysical economy, 1961-2008: sustainability in a national and global context. Ecological Economics 76: 60-69.

Tana River District Development Plan 2002-2008. Nairobi: Ministry of Planning and National Development.

Terer, T., G.G. Ndiritu, and N.N. Gichuki. 2004. Socio-economic values and traditional strategies of managing wetland resources in Lower Tana River, Kenya. Hydrobiologia 527: 3-14.

Upton, C. 2014. The new politics of pastoralism: identity, justice and global activism. Geoforum 54: 207216.

Vitousek, P.M., P.R. Ehrlich, A.H. Ehrlich, and P.A. Matson. 1986. Human appropriation of the products of photosynthesis. BioScience 36: 363-373.

Walker, P.A. 2005. Political ecology: where is the ecology? Progress in Human Geography 29(1): $73-82$.

Wright, D.H. 1983. Species-energy theory: an extension of species-area theory. Oikos 41: 496-506.

Zoomers, A. 2010. Globalisation and the foreignisation of space: seven processes driving the current global land grab. Journal of Peasant Studies 37(2): 429-447. 